\title{
Environmental Life-Cycle Analysis of Hybrid Solar Photovoltaic/Thermal Systems for Use in Hong Kong
}

\author{
Tin-Tai Chow ${ }^{1}$ and Jie Ji² \\ ${ }^{1}$ BEETRU, Division of Building Science and Technology, City University of Hong Kong, Kowloon, Hong Kong \\ ${ }^{2}$ Department of Thermal Science and Energy Engineering, University of Science and Technology of China, Hefei 230026, China
}

Correspondence should be addressed to Tin-Tai Chow, bsttchow@cityu.edu.hk

Received 4 May 2012; Accepted 15 August 2012

Academic Editor: Christophe Menezo

Copyright (C 2012 T.-T. Chow and J. Ji. This is an open access article distributed under the Creative Commons Attribution License, which permits unrestricted use, distribution, and reproduction in any medium, provided the original work is properly cited.

\begin{abstract}
While sheet-and-tube absorber is generally recommended for flat-plate photovoltaic/thermal (PV/T) collector design because of the simplicity and promising performance, the use of rectangular-channel absorber is also tested to be a good alternative. Before a new energy technology, like PV/T, is fully implemented, its environmental superiority over the competing options should be assessed, for instance, by evaluating its consumption levels throughout its production and service life. Although there have been a plenty of environmental life-cycle assessments on the domestic solar hot water systems and PV systems, the related works on hybrid solar PV/T systems have been very few. So far there is no reported work on the assessment of PV/T collector with channel-type absorber design. This paper reports an evaluation of the energy payback time and the greenhouse gas payback time of free-standing and building-integrated PV/T systems in Hong Kong. This is based on two case studies of PV/T collectors with modular channeltype aluminium absorbers. The results confirm the long-term environmental benefits of PV/T applications.
\end{abstract}

\section{Introduction}

A photovoltaic/thermal (PV/T) system is a combination of photovoltaic (PV) and solar thermal devices that generate both electricity and heat energy from one integrated system. With solar cells as (part of) the thermal absorber, the hybrid design is able to maximize the energy output from an allocated space reserved for solar application. Air and/or water can be used as the heat removal fluid(s) to lower the solar cell working temperature and to improve the electricity conversion efficiency. Comparatively, the water-type product design provides more effective cooling than the air-type counterpart because of the favorable thermal properties. Those with flat plate collectors meet well the low temperature water heating system requirements. They are also ideal for preheating purposes when hot water at higher temperature is required.

While sheet-and-tube absorber is one common feature in flat-plate collectors, the use of rectangular-channel absorbers also has been examined extensively [1-3]. An aluminum water-in-channel-type $\mathrm{PV} / \mathrm{T}$ collector design is recommended by the authors, with the prototypes well-tested under both free-standing and building-integrated manners $[4,5]$. Through the adoption of the channel absorber design, the potential problem of low fin efficiency can be readily improved. Based on the thermosyphon working principle, the collector performance is found to have geographical dependence and working well at the warmer climate zones. In the Asia Pacific region, most large cities are dominated by air-conditioned buildings where space cooling demands are high. In these buildings, the exposed facades provide very good opportunity for accommodating the building integrated systems, hence, the BiPV/T. When a part of the solar radiation that falls on the building façade is directly converted to useful thermal and electric power, the portion of solar energy transmitted through the external facade is reduced. Hence, the space cooling load is reduced. Through dynamic simulation with the use of experimentally validated system models and the typical meteorological year (TMY) data of Hong Kong, the cost payback time (CPBT) of freestanding and building-integrated PV/T systems were found 12.1 and 13.8 years, respectively $[6,7]$. The assessments were taken, respectively, at their best tilted and vertical collector positions for maximizing their system outputs. It is expected 
that these CPBT will be gradually shortened as the PV technology is in progressive advancement. In this paper, the environmental life-cycle analysis (LCA) of such hybrid solar systems as applied in Hong Kong is reported.

\section{Environmental Life-Cycle Analysis}

LCA is a technique for assessing various aspects associated with development of a product and its potential impact throughout a product's life [8]. Before a new energy technology is fully implemented, the environmental superiority over competing options can be asserted by evaluating its consumption levels (such as cost investments, energy uses, and GHG emissions) throughout its entire production and service life. In terms of economic analysis, a simplified approach is to ignore the time element so the cost payback time (CPBT) can be used. This is by adding together the cash inflows from successive years until the cumulative cash inflow is the same as the required investment. In analogy to the economical evaluation, two environmental cost-benefit parameters, the energy payback time (EPBT) and greenhouse gas payback time (GPBT), can be used to evaluate the time period after which the real environmental benefit starts [9]. EPBT is the period that a system has to be in operation in order to save the amount of primary energy that has been spent for production, operation, and maintenance of the system. It is the ratio of embodied energy to annual net energy output. In a BiPV/T system, for example,

$$
\mathrm{EPBT}=\frac{\sum_{\mathrm{pvt}}+\sum_{\mathrm{bos}}-\sum_{\mathrm{mtl}}}{E_{\mathrm{pv}}+E_{t}+E_{\mathrm{ac}}-E_{\mathrm{om}}},
$$

where $\sum_{\text {pvt }}, \sum_{\text {bos }}$ and $\sum_{\mathrm{mtl}}$, are, respectively, the embodied energy of the PV/T collectors, of the balance of system (BOS), and of the replaced building materials; $E_{\mathrm{pv}}$ is the annual useful electricity output, $E_{t}$ the annual useful heat gain (equivalent), $E_{\mathrm{ac}}$ the annual electricity saving of the HVAC system due to the space thermal load reduction, and $E_{\text {om }}$ is the annual electricity consumed in system operation and maintenance activities. $\sum_{\mathrm{mtl}}$ and $E_{\mathrm{ac}}$ can be omitted in free-stand PV/T system evaluation. Hence,

$$
\mathrm{EPBT}=\frac{\sum_{\mathrm{pvt}}+\sum_{\mathrm{bos}}}{E_{\mathrm{pv}}+E_{t}-E_{\mathrm{om}}} .
$$

Similarly, in terms of greenhouse gas (GHG) emission, for $\mathrm{BiPV} / \mathrm{T}$

$$
\mathrm{GPBT}=\frac{\Omega_{\mathrm{pvt}}+\Omega_{\mathrm{bos}}-\Omega_{\mathrm{mtl}}}{Z_{\mathrm{pv}}+Z_{t}+Z_{\mathrm{ac}}},
$$

where $\Omega$ stands for the embodied GHG (or carbon dioxide equivalent) emission and $Z$ the reduction of annual GHG emission from the local power plant owing to the BiPV/T operation. And for the free-stand system,

$$
\mathrm{GPBT}=\frac{\Omega_{\mathrm{pvt}}+\Omega_{\mathrm{bos}}}{Z_{\mathrm{pv}}+Z_{t}} .
$$

Thus EPBT and GPBT are functions of the related energy system performance and their environmental impacts, like

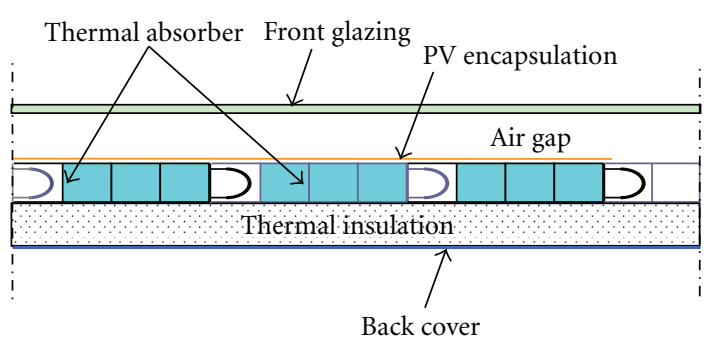

FIgure 1: Cross-sectional view of the PV/T collector showing several absorber modules in integration (N.T.S).

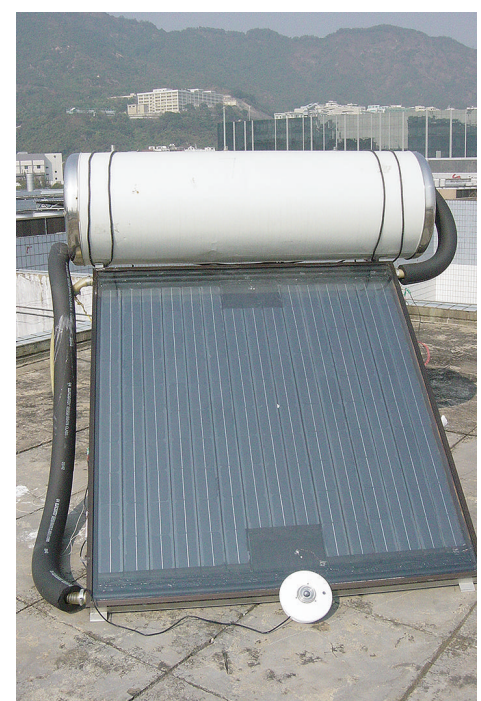

Figure 2: Front view of free-stand PV/T collector system.

those of the power utilities, the building systems, local and overseas manufacturing, and transportation and on-site handling of $\mathrm{PV} / \mathrm{T}$ collector system as a whole.

\section{Aluminum Rectangular-Channel PV/T Systems}

The sectional view of an aluminum rectangular-channel $\mathrm{PV} / \mathrm{T}$ collector developed by the authors is shown in Figure 1. It is composed of the following layers: (i) front low-iron glass cover, (ii) crystalline silicon (c-Si) PV encapsulation, (iii) metallic thermal absorber constructed from extruded aluminum, (iv) thermal insulation layer with glass wool, and (v) back-cover steel sheet. The PV encapsulation includes TPT (tedlar-polyester-tedlar) and EVA (ethylene-vinyl acetate) layers at both sides of the solar cells. The rectangular-channel design strengthens the heat transfer and structural durability.

In a free-stand thermosyphon system, the PV/T collector carries a water tank with the natural water circulation via inter-connecting pipes. Figure 2 shows the external view. Water enters the collector at the lower header and leaves via the upper header. Table 1 lists the technical data of this PV/T collector for free-stand applications. 


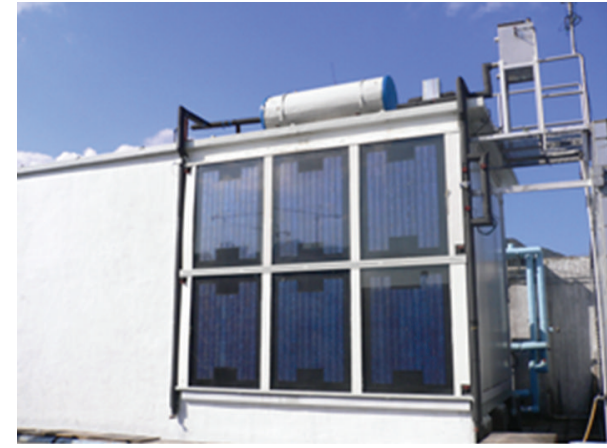

Figure 3: Front view of BiPV/T system with water tank at top of wall.

A BiPV/T system, on the other hand, is composed of an array of $\mathrm{PV} / \mathrm{T}$ collectors that are integrated to the external wall of an air-conditioned building. See Figure 3 for reference. The water tank is located at the roof-top and the water circulation is again by means of thermosyphon. Table 2 lists the technical data of the BiPV/T wall system in our study.

\section{Review of Previous Works on Flat Plate Collector Systems}

4.1. Solar Hot Water Systems. The LCA works on domestic solar hot water (DSHW) systems in majority were from EU countries [10-13]. Streicher et al. [10] evaluated the EPBT of solar thermal systems by dividing the system into components. The cumulative energy demand was obtained by multiplying the weight of the main components with their respective cumulative energy demand values. They estimated that in Germany the DSHW systems have EPBT from 1.3 to 2.3 years. In their study, construction credit was given to the collector system in integrated roof-mounting mode. This is for the savings in building materials, transportation, and construction works. The collector itself accounts for $89 \%$ and $85 \%$ of the total embodied energy in the roof-integrated and open-stand systems, respectively. Tsilingiridis et al. [11] found that in Greece the materials used, including steel and copper, have the major contribution to the environmental impacts. Ardente et al. [12] found that in Italy the indirect emissions (related to production of raw materials) are about 80-90\% of the overall GHG releases. Kalogirou [13] worked on a thermosyphon DSHW system in Cyprus. The system thermal performance was evaluated by dynamic simulation program. The LCA determined that $77 \%$ of the embodied energy goes to the collector panels, $15 \%$ goes to the steel frame, $5 \%$ goes to piping, and the remaining accounts for less than 3\% of the total. Considerable amounts of GHG can be saved. The EPBT was estimated around 1.1 year.

Outside Europe, the study of Crawford et al. [14] in Australia showed that although the CPBT of DSHW systems can be 10 years or more, the corresponding GPBT can be only around $2.5-5$ years. In their study, a conversion factor of $60 \mathrm{~kg} \mathrm{CO}$ eq/GJ was used to determine the GHG emission
TABLE 1: Collector and technical design data of free-stand PV/T system.

\begin{tabular}{lc}
\hline Design parameters & Data \\
\hline Thickness & Glazing (low-iron glass) \\
Emissivity & $0.004 \mathrm{~m}$ \\
Extinction coefficient & 0.88 \\
Refraction index & $26 / \mathrm{m}$ \\
Depth of air gap & 1.526 \\
underneath & $0.025 \mathrm{~m}$ \\
\hline
\end{tabular}

PV encapsulation

$(\mathrm{TPT}+\mathrm{EVA}+$ solar cell $+\mathrm{EVA}+\mathrm{TPT}+$ silicon gel $)$

\begin{tabular}{|c|c|}
\hline Solar cell type & single-crystalline silicon \\
\hline Cell area & $1.11 \mathrm{~m}^{2}$ \\
\hline $\begin{array}{l}\text { Cell electrical efficiency at } \\
\text { STC }\end{array}$ & $13 \%$ \\
\hline $\begin{array}{l}\text { Solar cell temperature } \\
\text { coefficient }\end{array}$ & $0.005 / \mathrm{K}$ \\
\hline Emissivity & 0.8 \\
\hline Absorptivity & 0.8 \\
\hline Packing factor (wrt glazing) & $63 \%$ \\
\hline \multicolumn{2}{|c|}{ Thermal absorber (Aluminum) } \\
\hline $\begin{array}{l}\text { No. of flat-box absorber } \\
\text { module }\end{array}$ & 15 \\
\hline Absorber module size & $0.105 \times 1.38 \times 0.012 \mathrm{~m}$ \\
\hline No. of header & 2 \\
\hline Header size & $1.575 \times 0.025($ dia. $) \times 0.002$ (thick $) \mathrm{m}$ \\
\hline \multicolumn{2}{|c|}{ Thermal insulation layer (glass wool) } \\
\hline Thickness & $0.03 \mathrm{~m}$ \\
\hline \multicolumn{2}{|c|}{ Back cover (galvanized iron) } \\
\hline Thickness & $0.001 \mathrm{~m}$ \\
\hline \multicolumn{2}{|c|}{ Water tank and connecting pipes } \\
\hline Water storage capacity & $155 \mathrm{~kg}$ \\
\hline Tank length & $1.2 \mathrm{~m}$ \\
\hline Tank diameter & $0.21 \mathrm{~m}$ \\
\hline Pipe diameter & $0.015 \mathrm{~m}$ \\
\hline $\begin{array}{l}\text { Thickness of insulation } \\
\text { layer at tank }\end{array}$ & $0.025 \mathrm{~m}$ \\
\hline $\begin{array}{l}\text { Thickness of insulation } \\
\text { layer on pipe }\end{array}$ & $0.02 \mathrm{~m}$ \\
\hline
\end{tabular}

from the cumulative energy of the entire system. Arif [15] evaluated the environmental performance of DSHW systems in India. Based on the 100 litre-per-day and steady year-round usage, the EPBT was estimated 1.6-2.6 years, all depending on the local climates and also the collector materials in use. In the LCA work of Hang et al. [16] on a range of solar hot water systems in USA; dynamic thermal simulation was again applied.

4.2. PV Systems. In the last decades, plenty of works have been reported on life cycle performance of PV systems in both free-stand and building-integrated manners. The 
TABLE 2: Collector and technical design data of BiPV/T system.

\begin{tabular}{|c|c|}
\hline Design parameters & Data \\
\hline \multicolumn{2}{|c|}{ Front glazing (low-iron glass) } \\
\hline Thickness & $0.004 \mathrm{~m}$ \\
\hline Surface area & $1.61 \mathrm{~m}^{2}$ \\
\hline Depth of air gap underneath & $0.025 \mathrm{~m}$ \\
\hline \multicolumn{2}{|c|}{$\begin{array}{l}\text { PV encapsulation } \\
(\mathrm{TPT}+\text { EVA + solar cell + EVA + TPT + silicon gel })\end{array}$} \\
\hline Solar cell type & single-crystalline silicon \\
\hline Cell area & $0.81 \mathrm{~m}^{2}$ \\
\hline Cell electrical efficiency at STC & $13 \%$ \\
\hline Solar cell temperature coefficient & $0.005 / \mathrm{K}$ \\
\hline Emissivity & 0.8 \\
\hline Absorptivity & 0.8 \\
\hline Packing factor (wrt glazing) & $50 \%$ \\
\hline \multicolumn{2}{|c|}{ Thermal absorber (aluminum alloy) } \\
\hline Thermal capacity & $903 \mathrm{~kJ} /(\mathrm{kg} \cdot \mathrm{K})$ \\
\hline Density & $2702 \mathrm{~kg} / \mathrm{m}^{3}$ \\
\hline Thermal conductivity & $237 \mathrm{~W} /(\mathrm{m} \cdot \mathrm{K})$ \\
\hline Emissivity & 0.8 \\
\hline Absorptivity & 0.9 \\
\hline \multicolumn{2}{|c|}{ Insulation material (glass wool) } \\
\hline Thickness & $0.03 \mathrm{~m}$ \\
\hline $\begin{array}{l}\text { Air gap between insulation layer and } \\
\text { building wall }\end{array}$ & $0.02 \mathrm{~m}$ \\
\hline \multicolumn{2}{|c|}{ Building wall (brick) } \\
\hline Thickness & $0.15 \mathrm{~m}$ \\
\hline Density & $1600 \mathrm{~kg} / \mathrm{m}^{3}$ \\
\hline Thermal capacity & $880 \mathrm{~J} /(\mathrm{kg} \cdot \mathrm{K})$ \\
\hline Thermal conductivity & $1.0 \mathrm{~W} /(\mathrm{m} \cdot \mathrm{K})$ \\
\hline \multicolumn{2}{|c|}{ Water tank (steel) and connecting pipes (copper) } \\
\hline Water storage capacity & $0.46 \mathrm{~m}^{3}$ \\
\hline Tank length & $1.5 \mathrm{~m}$ \\
\hline Tank diameter & $0.54 \mathrm{~m}$ \\
\hline Pipe diameter & $0.055 \mathrm{~m}$ \\
\hline Thickness of insulation layer at tank & $0.025 \mathrm{~m}$ \\
\hline Thickness of insulation layer on pipe & $0.02 \mathrm{~m}$ \\
\hline
\end{tabular}

estimations of EPBT and GPBT have been kept on revising owing to the advancements in PV technology.

The production of a PV module includes the following processes:

(i) silicon purification and processing,

(ii) silicon ingot slicing, and

(iii) PV module fabrication.

Silica is first melted and manufactured into metallurgical-grade silicon (MG-Si), then into electronic silicon (EG$\mathrm{Si}$ ) through the Siemen's process or into solar-grade silicon (SoG-Si) through the modified Siemens process [17]. Finally, after the Czochralski process (for sc-Si) or other production process, silicon is made available for the solar cell production.
The silicon ingot is needed to be sliced into wafer. The technologies of cell production include etching, doping, screen printing, and coating. The solar cells are then tested, packed, and interconnected with other components to form PV modules.

Alsema [18] studied the EPBT and the GHG emissions of grid-connected PV systems. The cumulative energy demands of sc-Si and mc-Si frameless modules were evaluated as 5700 and $4200 \mathrm{MJ} / \mathrm{m}^{2}$. Further, it was pointed out that with the implementation of new manufacturing technologies, the above data could be as low as 3200 and $2600 \mathrm{MJ} / \mathrm{m}^{2}$. Later on, Alsema et al. $[19,20]$ reviewed the important options that were available for further reduce energy consumption and environment impacts of the PV module production processes. As for BOS, Alsema and Nieuwlaar [21] presented that because of the less use of aluminum in supporting structure, the energy requirement for array support of ground-mounted PV system was about $1800 \mathrm{MJ} / \mathrm{m}^{2}$, but this could be only $700 \mathrm{MJ} / \mathrm{m}^{2}$ for rooftop installation; hence rooftop systems should have better potentials for EPBT reduction than ground-mounted systems.

Mason et al. [22] studied the energy contents of the BOS components used in a 3.5 MWp mc-Si PV plant. By integrating the weight of the PV modules with the supports, the embodied energy of the BOS components was found as low as $542 \mathrm{MJ} / \mathrm{m}^{2}$ - a sharp reduction from the previous estimations. Fthenakis and Kim [23] showed that in Japan the primary energy demand for sc-Si PV module was in the range of $4160-15520 \mathrm{MJ} / \mathrm{m}^{2}$, and the life-cycle GHG emissions rate for PV systems in the United States were from 22 to $49 \mathrm{~g} \mathrm{CO}_{2}$-eq/ $\mathrm{kWh}_{\mathrm{e}}$.

In Singapore, Kannan et al. studied a $2.7 \mathrm{kWp}$ distributed PV system with sc-Si modules [24]. Specific energy consumptions for the PV modules and the inverters were estimated 16 and $0.17 \mathrm{MWh}_{\mathrm{e}} / \mathrm{kWp}$ respectively. The manufacturing of solar PV modules accounted for $81 \%$ of the life cycle energy use. The aluminium supporting structure accounted for about $10 \%$, and the recycling of aluminium accounted for another 7\%. The EPBT was estimated to be 6.74 years. It was claimed that this can be reduced to 3.5 years if the primary energy use on PV module production is reduced by $50 \%$.

In India, Nawaz and Tiwari [25] calculated EPBT by evaluating the energy requirement for manufacturing a sc-Si PV system for open field and rooftop conditions with BOS. Mitigation of $\mathrm{CO}_{2}$ emissions at macrolevel (where lifetime of battery and PV system are the same) and microlevel of the PV system has also been studied. For a $1 \mathrm{~m}^{2} \mathrm{sc}-\mathrm{Si}$ PV system, their estimations give an embodied energy of $666 \mathrm{kWh}$ for silicon purification and processing, $120 \mathrm{kWh}$ for cell fabrication, and $190 \mathrm{kWh}$ for subsequent PV module production. Hence without BOS, the embodied energy was estimated $976 \mathrm{kWh} / \mathrm{m}^{2}$ and the $\mathrm{GHG}$ emission was $27.23 \mathrm{~kg} / \mathrm{m}^{2}$.

In Hong Kong Lu and Yang [26] investigated the EPBT and GPBT of a roof-mounted $22 \mathrm{~kW}$ BiPV system. It was found that $71 \%$ of the embodied energy on the whole is from the embodied energy of the PV modules, whereas the remaining $29 \%$ is from the embodied energy of BOS. The 
EPBT of the PV system was then calculated as 7.3 years. Considering the fuel mixture composition of local power stations, the corresponding GPBT is 5.2 years. Further, it was predicted that the possible range of EPBT of BiPV installations in Hong Kong is from 7.1 years (for optimal orientation) to 20 years (for west-facing vertical façade).

Bankier and Gale [27] gave a review of EPBT of roof mounted PV systems reported in the 10-year period (19962005). A large range of discrepancy was found. They pointed out that the limitations to the accuracy of the assessments came from the difficulties in determining realistic energy conversion factors, and in determining realistic energy values for human labor. According to their estimation, the appropriate range of EPBT for mc-Si PV module installations should be between 2-8 years. A more recent review was done by Sherwani et al. [28]. The EPBT for sc-Si, mc-Si, and aSi PV systems have been estimated in the ranges of 3.2$15.5,1.5-5.7$, and 2.5-3.2, years, respectively. Similarly, GHG emissions are 44-280, 9.4-104, and 15.6-50 g CO $\mathrm{CO}_{2}$-eq/kWh.

4.3. PV/T Systems. While there have been plenty studies of EPBT and GPBT on solar thermal and PV systems, our literature review shows that those on $\mathrm{PV} / \mathrm{T}$ systems have been very few. In particular, there is so far no reported work on the assessment of PV/T collectors with channel-type absorber design.

Battisti and Corrado [29] made evaluation based on a conventional mc-Si building-integrated system located in Rome, Italy. An experimental PV/T system with heat recovery for DSHW application was examined. Evaluations were made for alternative heat recovery to replace either natural gas or electricity. Their results give the EPBT and GPBT of PV system as 3.3 and 4.1 years. On the other hand, those of the PV/T systems designed for natural gas replacement are 2.3 and 2.4 years.

Also in Italy, Tripanagnostopoulos et al. [30] evaluated the energy and environmental performance of their modified $3 \mathrm{kWp}$ mc-Si PV and experimental water-cooled PV/T sheetand-tube collector systems designed for horizontal-roof (free-stand) and tilted-roof (building integrated) installations. The application advantage of the glazed/unglazed $\mathrm{PV} / \mathrm{T}$ over the PV options was demonstrated through the better LCA performances. The EPBT of the PV and BiPV system were found to be 2.9 and 3.2 years, whereas the GPBT were 2.7 and 3.1 years, respectively. For PV/T system with $35^{\circ} \mathrm{C}$ operating temperature, the EPBT of the PV/T and $\mathrm{BiPV} / \mathrm{T}$ options were both 1.6 years, and the GPBT were 1.9 and 2.0 years respectively. The study showed that nearly the whole of the environmental impacts are due to PV module production, aluminium parts (reflectors and heat-recoveryunit) as well as copper parts (for heat-recovery-unit and hydraulic circuit), with barely significant contributions from the other system components, such as support structures or electrical/electronic devices. The disposal phase contribution is again almost negligible.

Dubey and Tiwari [31] carried out an environmental impact analysis of a hybrid PV/T solar water heater for use in the Delhi climate of India. With a glazed sheet-and-tube flat plate collector system designed for pump operation, the EPBT was found 1.3 years.

\section{Environmental Analysis of Aluminum Rectangular-Channel PV/T Systems}

5.1. EPBT of Free-Stand System. Skillful lamination of solar cell onto thermal absorber with layers of EVA and TPT is needed for PV/T collector production. Aluminum thermal absorber parts are made available by raw material mining and extraction, ingot melting, mechanical extrusion, machining, and assembling into whole piece. The majorcomponent production and assembly processes include front glass (low iron), PV-laminated absorber, insulation material and aluminum frame. The supply was from the mainland. As for the BOS, the electrical BOS components include inverters, electrical wirings, and electronic devices. The mechanical BOS include water storage tank, pipe work, supporting structure, and accessories. The embodied energy to be considered in the LCA include the above during production, plus those related to the required transportation from factory to installation site, construction and testing, decommissioning and disposal, and any other end-of-life energy requirements.

Table 3 summarizes the materials used and cumulative energy of the free-stand PV/T collector system. The cumulative energy intensity of sc-Si PV module was estimated as $976 \mathrm{kWh} / \mathrm{m}^{2}$, making references to $[25,26]$. That of the inverter and electrical parts was taken as 5\% of the PV module. The other values of cumulative energy intensity in MJ/unit was obtained from the Hong Kong government EMSD (Electrical and Mechanical Services Department) database that covers the specific (per unit quantity) impact profile due to consumption of materials in the "Cradle-to-As-built" stage [32]. The total cumulative energy comes up to $3041.8 \mathrm{kWh}$ or $1728 \mathrm{kWh} / \mathrm{m}^{2}$ for this free-stand system. Table 4 shows the distribution of the embodied energy in this case. It can be seen that the hybrid PV/T collector itself accounts for around $80 \%$ of the embodied energy. For the BOS, the water tank accounts for $11.4 \%$, the other mechanical components accounts for $7 \%$, whereas the electrical accessories accounts for only $1.8 \%$. $\sum_{\text {pvt }}$ and $\sum_{\text {bos }}$ are then 2429 and $613 \mathrm{kWh}$, respectively.

With the installation of this PV/T system, two kinds of energy saving are involved: thermal energy for water heating and electrical energy. This will be no air-conditioning saving. A thermal energy saving of $2650 \mathrm{MJ} /$ year and electricity saving of $473 \mathrm{MJ} /$ year give an $E_{t}$ of $736 \mathrm{kWh} /$ year and an $E_{\mathrm{pv}}$ of $398 \mathrm{kWh} /$ year. In the computation, a heat-to-electricity conversion factor of 0.33 has been used. Mainly labor costs were considered in $E_{\text {om }}$. This is estimated as $41 \mathrm{kWh} /$ year and is therefore not significant. With (2), the EPBT is found 2.8 years. This is much shorter than the expected CPBT of 12.1 years reported in our previous work [6]. Assuming that the working life of PV/T system is similar to PV system, that is, 15-30 years in general [29], then it can be concluded that 
TABLE 3: Cumulative energy in free-stand PV/T system.

\begin{tabular}{|c|c|c|c|}
\hline Materials & $\begin{array}{l}\text { Quantity } \\
\text { consumed } \\
(\mathrm{kg})\end{array}$ & $\begin{array}{c}\text { Cumulative } \\
\text { energy intensity } \\
\text { (MJ/unit) }\end{array}$ & $\begin{array}{c}\text { Cumulative } \\
\text { energy }(\mathrm{kWh})\end{array}$ \\
\hline \multicolumn{4}{|c|}{ PV/T collector } \\
\hline \multicolumn{4}{|c|}{ Front glazing } \\
\hline $\begin{array}{l}\text { Low-iron glass } \\
\left(1.76 \mathrm{~m}^{2}\right)\end{array}$ & 19.7 & 19.7 & 107.9 \\
\hline \multicolumn{4}{|c|}{ Thermal insulation } \\
\hline Glass wool & 1.69 & 31.7 & 14.9 \\
\hline \multicolumn{4}{|c|}{ Thermal absorber } \\
\hline $\begin{array}{l}\text { Aluminum } \\
\text { absorber }\end{array}$ & 18.3 & 219 & 1114.7 \\
\hline \multicolumn{4}{|c|}{ Frame and back cover } \\
\hline Aluminum & 1.78 & 219 & 108.0 \\
\hline \multicolumn{4}{|c|}{ PV Encapsulation } \\
\hline PV Module & $1.11 \mathrm{~m}^{2}$ & 976 & 1083.4 \\
\hline \multicolumn{4}{|c|}{ BOS } \\
\hline \multicolumn{4}{|c|}{ Water tank } \\
\hline $\begin{array}{l}\text { Stainless steel } \\
\text { tank }\end{array}$ & 4.20 & 82.2 & 273.0 \\
\hline $\begin{array}{l}\text { Tank insulation } \\
\text { (Glass wool) }\end{array}$ & 1.58 & 31.7 & 13.9 \\
\hline $\begin{array}{l}\text { Aluminum } \\
\text { Cladding }\end{array}$ & 0.966 & 219 & 58.8 \\
\hline \multicolumn{4}{|c|}{ Connecting pipe } \\
\hline $\begin{array}{l}\text { Copper piping } \\
\text { (15 mm dia.) }\end{array}$ & $2.4 \mathrm{~m}$ & 6.33 & 4.2 \\
\hline $\begin{array}{l}\text { Pipe insulation } \\
\text { (Glass wool) }\end{array}$ & 0.0627 & 31.7 & 0.6 \\
\hline \multicolumn{4}{|c|}{ Structural support and accessories } \\
\hline Steel stand & 14.2 & 29.2 & 115.2 \\
\hline $\begin{array}{l}\text { Pipe fittings and } \\
\text { structural joints }\end{array}$ & 7.19 & 140.0 & 93.3 \\
\hline \multirow[t]{2}{*}{$\begin{array}{l}\text { Inverter }+ \\
\text { electric wiring }\end{array}$} & $5 \% \mathrm{o}$ & PV module & 54.2 \\
\hline & & Total: & 3041.8 \\
\hline
\end{tabular}

TABle 4: Distribution of embodied energy in PV/T collector systems.

\begin{tabular}{lccc}
\hline \multicolumn{2}{c}{ System component description } & Free-stand & BiPV/T \\
\hline \multirow{2}{*}{ PV/T Collector } & Mechanical components & 44.2 & 51.8 \\
& Electrical components & 35.6 & 37.7 \\
\hline \multirow{3}{*}{ BOS } & Water tank & 11.4 & 4.9 \\
& Pipe and structural supports & 7.0 & 3.8 \\
& Electrical components & 1.8 & 1.9 \\
\hline
\end{tabular}

the EPBT in this case study is an order of magnitude lower than its expected working life.

5.2. BiPV/T System. Table 5 summarizes the materials used and the cumulative energy in the $9.66 \mathrm{~m}^{2} \mathrm{BiPV} / \mathrm{T}$ case. Accordingly, the values of $Z_{\text {pvt }}$ and $Z_{\text {bos }}$ are, respectively,
TABLE 5: Cumulative energy in BiPV/T system.

\begin{tabular}{|c|c|c|c|}
\hline Materials & $\begin{array}{c}\text { Quantity } \\
\text { consumed } \\
(\mathrm{kg})\end{array}$ & $\begin{array}{c}\text { Cumulative } \\
\text { energy intensity } \\
\text { (MJ/unit) }\end{array}$ & $\begin{array}{c}\text { Cumulative } \\
\text { energy } \\
(\mathrm{kWh})\end{array}$ \\
\hline \multicolumn{4}{|c|}{$\mathrm{PV} / \mathrm{T}$ collector } \\
\hline \multicolumn{4}{|c|}{ Front glazing } \\
\hline $\begin{array}{l}\text { Low-iron glass } \\
\left(1.61 \mathrm{~m}^{2} \times 6\right)\end{array}$ & 99.6 & 19.7 & 545.0 \\
\hline \multicolumn{4}{|c|}{ Thermal insulation } \\
\hline Glass wool & 9.50 & 31.7 & 83.7 \\
\hline \multicolumn{4}{|c|}{ Thermal absorber } \\
\hline Aluminum absorber & 86.7 & 219 & 5273.8 \\
\hline \multicolumn{4}{|c|}{ Frame and back cover } \\
\hline Aluminum & 10.1 & 219 & 611.8 \\
\hline \multicolumn{4}{|c|}{ PV Encapsulation } \\
\hline PV Module & $4.86 \mathrm{~m}^{2}$ & 976 & 4743.4 \\
\hline \multicolumn{4}{|c|}{ BOS } \\
\hline \multicolumn{4}{|c|}{ Water tank } \\
\hline Stainless steel tank & 19.9 & 82.2 & 454.0 \\
\hline $\begin{array}{l}\text { Insulation (Glass } \\
\text { wool) }\end{array}$ & 2.14 & 31.7 & 18.8 \\
\hline Aluminum Cladding & 1.53 & 219 & 93.0 \\
\hline \multicolumn{4}{|c|}{ Connecting pipe } \\
\hline $\begin{array}{l}\text { Copper piping } \\
\text { ( } 55 \mathrm{~mm} \text { dia.) }\end{array}$ & $7 \mathrm{~m}$ & 40.1 & 77.9 \\
\hline $\begin{array}{l}\text { Pipe insulation } \\
\text { (Glass wool) }\end{array}$ & 1.07 & 31.7 & 9.4 \\
\hline \multicolumn{4}{|c|}{ Structural support and accessories } \\
\hline $\begin{array}{l}\text { Pipe fittings and } \\
\text { structural parts }\end{array}$ & 5.25 & 140.0 & 68.1 \\
\hline \multirow[t]{2}{*}{$\begin{array}{l}\text { Inverter + electric } \\
\text { wiring }\end{array}$} & \multicolumn{2}{|c|}{$5 \%$ of PV module } & 237.2 \\
\hline & & Total & 12585.2 \\
\hline
\end{tabular}

11258 and $1328 \mathrm{kWh} . Z_{\mathrm{mtl}}$ is estimated as $594 \mathrm{kWh}$, making reference to the work of Streicher et al. [10] and adjusted by the cost of living. Taking the advantage of building material replacement, the cumulative energy intensity reduces to $1241 \mathrm{kWh} / \mathrm{m}^{2}$. The embodied energy distribution of this $\mathrm{BiPV} / \mathrm{T}$ system is also given in Table 4 . It can be seen that for this building integrated case the portion of the collector increases to $89 \%$. For the BOS, the water tank accounts for $4.9 \%$, the pipe and supporting components account for $3.8 \%$, and the electrical components remain at less than $2 \%$.

With the installation of this BiPVW system, the annual energy savings include the following:

(i) thermal energy: $2258 \mathrm{kWh}\left(E_{t}\right)$;

(ii) electrical energy: $323 \mathrm{kWh}$;

(iii) space cooling load: $206 \mathrm{kWh}$.

By taking the COP of air-conditioning plant as 3.0, $E_{\mathrm{pv}}$ and $E_{\mathrm{ac}}$ are then 979 and $208 \mathrm{kWh} /$ year, respectively. In this case $E_{\mathrm{om}}$ is $246 \mathrm{kWh} /$ year, by estimation. By (1), the EPBT is 3.8 years, which is much shorter than its CPBT of 
13.8 years. A longer period of EPBT in this BiPV/T than in the free-stand case is mainly because of its vertical collector position as compared to the best angle of tilt, and also the differences in collector size and solar cell packing factor. A shorter EPBT is expected if ms-Si cell modules were used in the analyses because of the lower energy consumption during the manufacturing process. As a matter of fact, this 3.8 years for vertical-mounted $\mathrm{BiPV} / \mathrm{T}$ is advantageous as compared to the 7.1 years [26] for an optimal-oriented roof-top BiPV system in Hong Kong.

5.3. GHG Emission Analysis. In our analysis, the thermal energy saving was taken as a save of town gas consumed in the building. The electrical energy saving was taken as a save in purchased electricity from the utilities. Based on the data provided by the Hong Kong government, the territory-wide emission factor of GHG coming from utility power generation is $0.7 \mathrm{~kg} \mathrm{CO}_{2}$-eq $/ \mathrm{kWh}_{\mathrm{e}}$ including the transmission losses [33]. As for town gas, the emission factors for $\mathrm{CO}_{2}, \mathrm{CH}_{4}$, and $\mathrm{N}_{2} \mathrm{O}$ are, respectively, $2.815 \mathrm{~kg} / \mathrm{unit}, 0.0446 \mathrm{~g} / \mathrm{unit}$ and $0.0099 \mathrm{~g} / \mathrm{unit}$, where 1 unit of town gas is equivalent to 48 $\mathrm{MJ}$ consumed. For the free-stand case, the above information gives an annual reduction in GHG emission of $285 \mathrm{~kg} \mathrm{CO}_{2}$ eq. The PV/T system itself does not produce polluting emissions during their daily operation. And in these days, most of the manufacturing activities of products consumed in Hong Kong are taking place in the Mainland, so the emission factor of China can be used in our embodied GHG assessment. In China, the primary energy consumption for power generation is $12.01 \mathrm{MJ} / \mathrm{kWh}_{\mathrm{e}}$ and the $\mathrm{CO}_{2}$ emission rate for coal-fired power plant is $24.7 \mathrm{~g} \mathrm{CO}_{2}$-eq/MJ [34], the embodied GHG intensity of the PV/T collector in this case is therefore $0.297 \mathrm{~kg} \mathrm{CO}$-eq $/ \mathrm{kWh}$ cumulative energy. The local emission factor was used for the BOS part since local acquisition was assumed. Accordingly, with (4) this approximation gives a GPBT of 3.2 years for the free-stand system.

Similarly, for the BiPVT system the saving in airconditioning energy is converted as electricity saving based on a system COP (coefficient of performance) of 3.0. With (3) this gives a GPBT of 4.0 years. The result is again lower than the previously estimated GPBT of 5.2 years for the general performance of BiPV systems in Hong Kong [26].

For completeness, Table 6 shows the technical data in the evaluation of their CPBT. Comparing with the freestand PV/T case, the BiPV/T system had a lower investment cost on unit collector area basis. This is because on one hand there were building materials saving and there was no requirement on the steel stands which is essential for tiltmounting of the free-stand PV/T collector. On the other hand, it was benefitted by the economy of scale for mass handling of the system components. During operation, however, the vertical collector position of the BiPV/T system made it disadvantageous in the quantity of year-round solar radiation received by the collector surface. At the same time, there would be greater transmission loss for a centralized energy system. The simulation results showed that the annual useful heat gains of the free-stand and the building integrated
TABLE 6: Evaluation of cost payback time.

\begin{tabular}{lcc}
\hline Investment: HK\$ & Free-stand PV/T [6] & BiPV/T [7] \\
\hline Water storage tank & 400 & 750 \\
Collector frame and support & 400 & 1800 \\
Modular thermal absorber & 600 & 2700 \\
Solar cells and encapsulation & 4000 & 17500 \\
Inverter & 700 & 1000 \\
Piping, wiring and accessories & 300 & 900 \\
Installation costs & 1500 & 3000 \\
\hline Total system costs $(\mathrm{HK} \$)$ & 7900 & 27650 \\
\hline Useful energy savings & $\mathrm{MJ}(\mathrm{kWh})$ & $\mathrm{MJ}(\mathrm{kWh})$ \\
\hline Thermal energy & $2650.4(736.2)$ & $8127.5(2257.6)$ \\
Electrical energy & $473.2(131.4)$ & $1162.4(322.9)$ \\
Space cooling load & - & $742.6(206.3)$ \\
\hline Cost savings: HK\$ $\$$. & 530.1 & 1625.5 \\
\hline Gaseous fuel at HK $\$ 0.2 / \mathrm{MJ}$ & 124.9 & 372.0 \\
Electricity at HK\$0.95/kWh & 655.0 & 1997.5 \\
Annual saving & 12.1 years & 13.8 years \\
\hline Cost payback time $(\mathrm{CPBT})$ &
\end{tabular}

Note: USD1 is equivalent to HK\$7.8.

cases are $418 \mathrm{kWh} / \mathrm{m}^{2}$ and $233 \mathrm{kWh} / \mathrm{m}^{2}$, respectively, on unit glazing area basis. And the electrical energy gains are $118 \mathrm{kWh} / \mathrm{m}^{2}$ and $66.4 \mathrm{kWh} / \mathrm{m}^{2}$ on unit PV cell area basis. These came out with the CPBT of 12.1 years for the freestand case and 13.8 years for the building integrated case.

Our above findings are generally in line with the estimations by other researchers based on their own collector designs and local applications. Nevertheless, it should be noted that the above picture is not static. It is expected that the continuing improvements in material and energy utilization and recycling will change the current environmental profiles. On the other hand, the progression in solar cell performance will also lead to better EPBT and GPBT.

\section{Conclusion}

An environmental life-cycle assessment has been done to evaluate the energy and environmental profiles of two cases of PV/T system application in Hong Kong. In both cases, aluminum rectangular-channel absorber in association with sc-Si PV encapsulation was adopted in the single-glazed flatplate PV/T collector design. In our analysis, the cumulative energy inputs and the embodied GHG emissions were determined by established methodology and technical data making reference to reported research works as well as local government publications. The annual thermal and electrical energy outputs were from results of dynamic simulation based on the TMY dataset of Hong Kong and validated PV/T system models. Our estimation shows that the EPBT of the free-stand PV/T system at the best angle of tilt is around 2.8 years, which is an order of magnitude lower than the expected system working life. In the vertical-mounted $\mathrm{BiPV} / \mathrm{T}$ case, this is 3.8 years which is again considerably better than the general performance of roof-top BiPV system 
in Hong Kong. The corresponding GPBT of 3.2 and 4.0 years as a result demonstrate the environmental superiority of this $\mathrm{PV} / \mathrm{T}$ option over many other competing renewable energy systems.

\section{Acknowledgment}

The work described in this paper was supported by a Grant from the Research Grants Council of the Hong Kong Special Administrative Region, China (Project no. CityU112009).

\section{References}

[1] B. Sandnes and J. Rekstad, "A photovoltaic/thermal (PV/T) collector with a polymer absorber plate. Experimental study and analytical model," Solar Energy, vol. 72, no. 1, pp. 63-73, 2002.

[2] C. Cristofari, G. Notton, P. Poggi, and A. Louche, "Modelling and performance of a copolymer solar water heating collector," Solar Energy, vol. 72, no. 2, pp. 99-112, 2002.

[3] Y. Tripanagnostopoulos, T. Nousia, M. Souliotis, and P. Yianoulis, "Hybrid photovoltaic/thermal solar systems," Solar Energy, vol. 72, no. 3, pp. 217-234, 2002.

[4] T. T. Chow, J. Ji, and W. He, "Photovoltaic-thermal collector system for domestic application," Journal of Solar Energy Engineering, Transactions of the ASME, vol. 129, no. 2, pp. 205209, 2007.

[5] T. T. Chow, W. He, A. L. S. Chan, K. F. Fong, Z. Lin, and J. Ji, "Computer modeling and experimental validation of a building-integrated photovoltaic and water heating system," Applied Thermal Engineering, vol. 28, no. 11-12, pp. 13561364, 2008.

[6] T. T. Chow, W. He, J. Ji, and A. L. S. Chan, "Performance evaluation of photovoltaic-thermosyphon system for subtropical climate application," Solar Energy, vol. 81, no. 1, pp. 123-130, 2007.

[7] T. T. Chow, A. L. S. Chan, K. F. Fong, Z. Lin, W. $\mathrm{He}$, and J. Ji, "Annual performance of building-integrated photovoltaic/water-heating system for warm climate application," Applied Energy, vol. 86, no. 5, pp. 689-696, 2009.

[8] ISO, (International Organization for Standardization) 14040 Standard, Environmental Management-Life cycle AssessmentPrinciples and Framework, 1997.

[9] G. N. Tiwari and R. K. Mishra, Advanced Renewable Energy Sources, RSC Publishing, Cambridge, UK, 2012.

[10] E. Streicher, W. Heidemann, and H. Müller-Steinhagen, "Energy payback time-a key number for the assessment of thermal solar systems," in Proceedings of EuroSun, pp. 20-23, Freiburg, Germany, June 2004.

[11] G. Tsilingiridis, G. Martinopoulos, and N. Kyriakis, "Life cycle environmental impact of a thermosyphonic domestic solar hot water system in comparison with electrical and gas water heating," Renewable Energy, vol. 29, no. 8, pp. 1277-1288, 2004.

[12] F. Ardente, G. Beccali, M. Cellura, and V. Lo Brano, "Life cycle assessment of a solar thermal collector," Renewable Energy, vol. 30, no. 7, pp. 1031-1054, 2005.

[13] S. Kalogirou, "Thermal performance, economic and environmental life cycle analysis of thermosiphon solar water heaters," Solar Energy, vol. 83, no. 1, pp. 39-48, 2009.

[14] R. H. Crawford, G. J. Treloar, B. D. Ilozor, and P. E. D. Love, "Comparative greenhouse emissions analysis of domestic solar hot water systems," Building Research and Information, vol. 31, no. 1, pp. 34-47, 2003.

[15] M. Arif, "Life cycle analysis and carbon credit earned by solar water heating system," International Journal of Research in Engineering and Applied Sciences, vol. 2, no. 2, pp. 1884-1905, 2012.

[16] Y. Hang, M. Qu, and F. Zhao, "Economic and environmental life cycle analysis of solar hot water systems in the United States," Energy and Buildings, vol. 45, pp. 181-188, 2012.

[17] N. Jungbluth, "Life cycle assessment of crystalline photovoltaics in the Swiss ecoinvent database," Progress in Photovoltaics: Research and Applications, vol. 13, no. 5, pp. 429-446, 2005.

[18] E. A. Alsema, "Energy pay-back time and $\mathrm{CO}_{2}$ emissions of PV systems," Progress in Photovoltaics Research and Applications, vol. 8, pp. 17-25, 2000.

[19] E. A. Alsema, M. J. de Wild-Scholten, and V. M. Fthenakis, "Environmental impacts of PV electricity generation, a critical comparison of energy supply options," in Proceedings of 21st European Photovoltaic Solar Energy Conference, Dresden, Germany, 2006.

[20] E. A. Alsema and M. J. de Wild-Scholten, "Reduction of the environmental impacts in crystalline silicon module manufacturing," in Proceedings of the 22nd European Photovoltaic Solar Energy Conference, Milan, Italy, 2007.

[21] E. A. Alsema and E. Nieuwlaar, "Energy viability of photovoltaic systems," Energy Policy, vol. 28, no. 14, pp. 999-1010, 2000.

[22] J. E. Mason, V. M. Fthenakis, T. Hansen, and H. C. Kim, "Energy payback and life-cycle $\mathrm{CO}_{2}$ emissions of the BOS in an optimized 3.5MW PV installation," Progress in Photovoltaics: Research and Applications, vol. 14, no. 2, pp. 179-190, 2006.

[23] V. M. Fthenakis and H. C. Kim, "Greenhouse-gas emissions from solar electric- and nuclear power: a life-cycle study," Energy Policy, vol. 35, no. 4, pp. 2549-2557, 2007.

[24] R. Kannan, K. C. Leong, R. Osman, H. K. Ho, and C. P. Tso, "Life cycle assessment study of solar PV systems: an example of a $2.7 \mathrm{kWp}$ distributed solar PV system in Singapore," Solar Energy, vol. 80, no. 5, pp. 555-563, 2006.

[25] I. Nawaz and G. N. Tiwari, "Embodied energy analysis of photovoltaic (PV) system based on macro- and micro-level," Energy Policy, vol. 34, no. 17, pp. 3144-3152, 2006.

[26] L. Lu and H. X. Yang, "Environmental payback time analysis of a roof-mounted building-integrated photovoltaic (BIPV) system in Hong Kong," Applied Energy, vol. 87, no. 12, pp. 3625-3631, 2010.

[27] C. Bankier and S. Gale, "Energy payback of roof mounted photovoltaic cells," The Environmental Engineer, vol. 7, no. 4, pp. 11-14, 2006.

[28] A. F. Sherwani, J. A. Usmani, and Varun, "Life cycle assessment of solar PV based electricity generation systems: a review," Renewable and Sustainable Energy Reviews, vol. 14, no. 1, pp. 540-544, 2010.

[29] R. Battisti and A. Corrado, "Evaluation of technical improvements of photovoltaic systems through life cycle assessment methodology," Energy, vol. 30, no. 7, pp. 952-967, 2005.

[30] Y. Tripanagnostopoulos, M. Souliotis, R. Battisti, and A. Corrado, "Energy, cost and LCA results of PV and hybrid PV/T solar systems," Progress in Photovoltaics: Research and Applications, vol. 13, no. 3, pp. 235-250, 2005.

[31] S. Dubey and G. N. Tiwari, "Life cycle cost analysis and carbon credit earned by PV/T solar water heater for Delhi climatic conditions," Open Environmental Sciences, vol. 2, pp. 15-25, 2008 . 
[32] Hong Kong Government, Life Cycle Assessment (LCA) and Life Cycle Costing (LCC) Tool for Commercial Building Developments in Hong Kong: User Manual, EMSD, Hong Kong SAR Government publication, 2005.

[33] "Hong Kong Government," Guidelines to Account for and Report on Greenhouse Gas Emission and Removals for Buildings (Commercial, Residential or Institutional Purposes) in Hong Kong, EMSD and EPD, Hong Kong SAR Government publication, 2008.

[34] M. Ito, K. Kato, K. Komoto, T. Kichimi, and K. Kurokawa, "A comparative study on cost and life-cycle analysis for $100 \mathrm{MW}$ very large-scale PV (VLS-PV) systems in deserts using m-Si, aSi, CdTe, and CIS modules," Progress in Photovoltaics: Research and Applications, vol. 16, no. 1, pp. 17-30, 2008. 


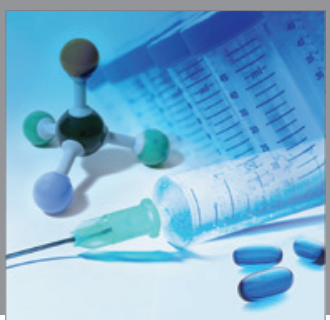

International Journal of

Medicinal Chemistry

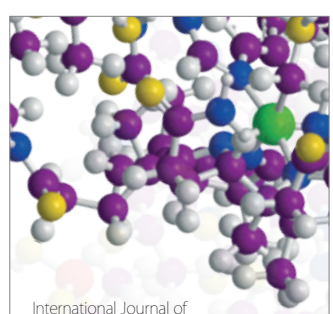

Carbohydrate Chemistry

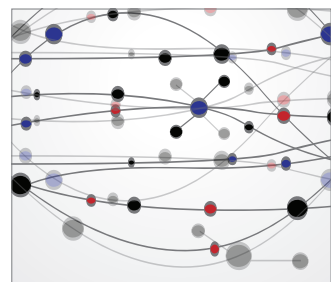

The Scientific World Journal
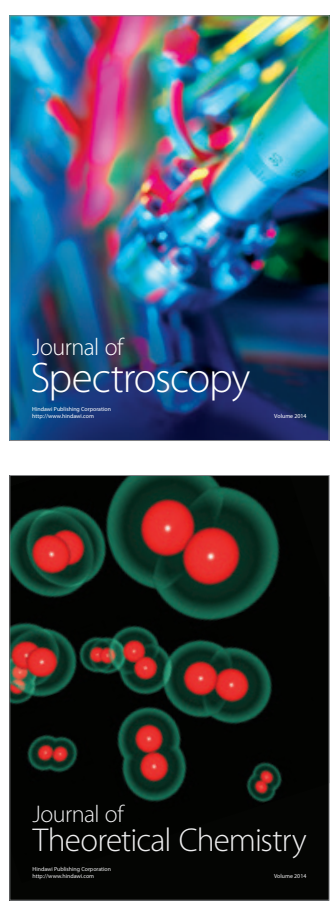
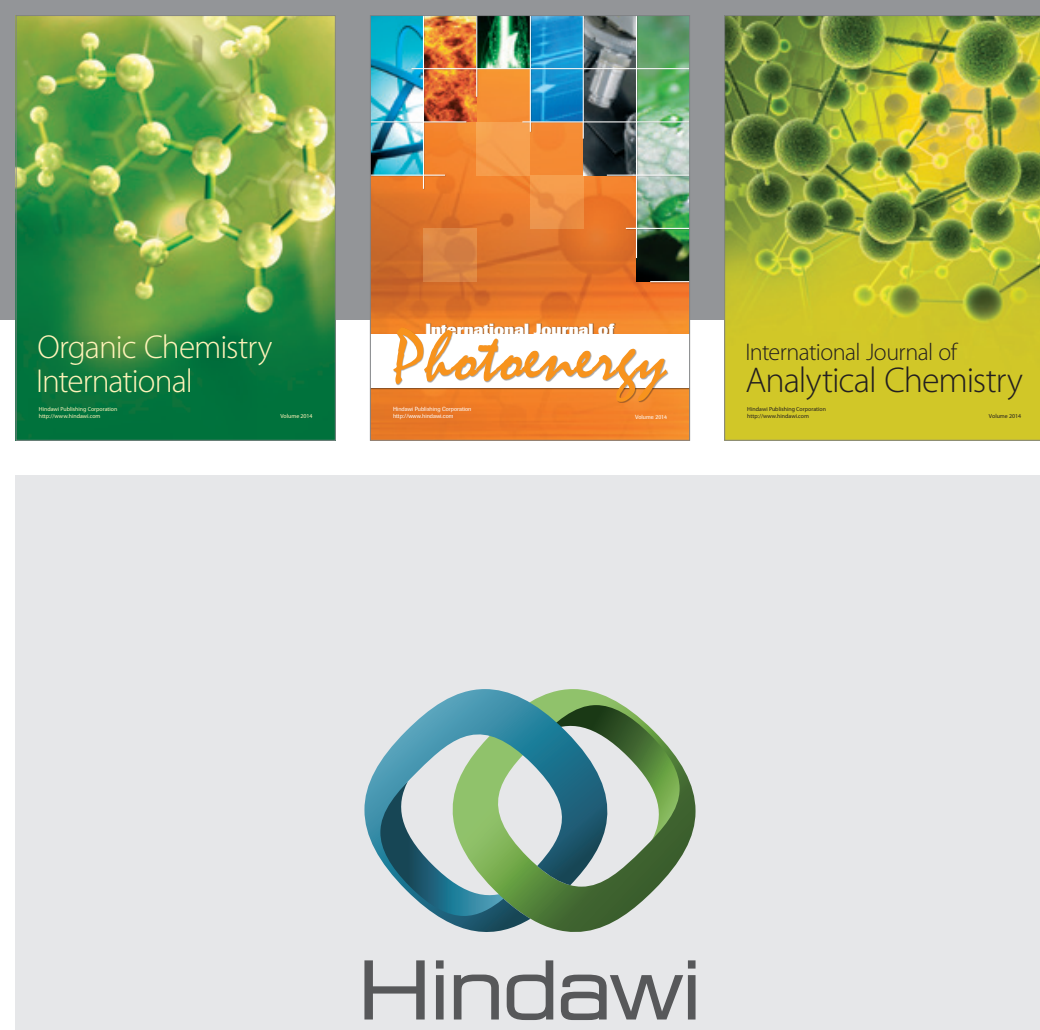

Submit your manuscripts at

http://www.hindawi.com
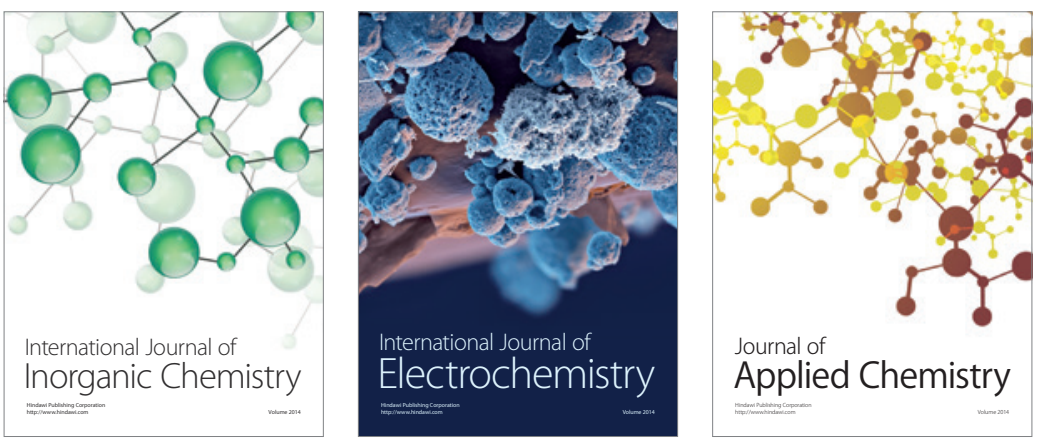

Journal of

Applied Chemistry
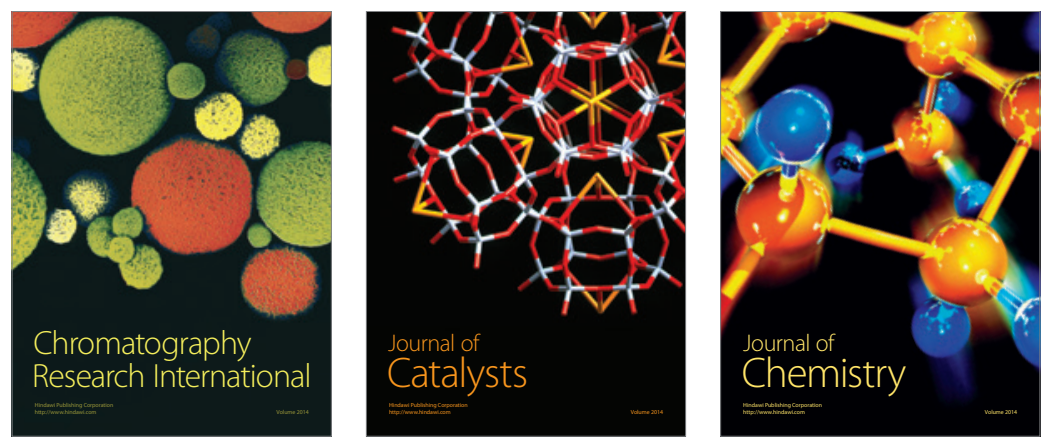
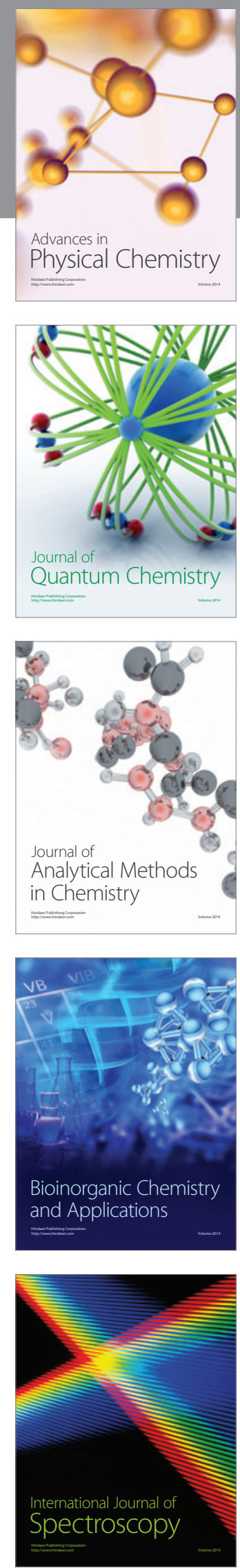